\title{
Strategies to Improve Financial Profitability in the Banking Industry
}

\author{
Khalid Said, DBA \\ Walden University, Minneapolis, Minnesota, United States \\ Yvonne Doll, DBA \\ Walden University, Minneapolis, Minnesota, United States \\ iD https://orcid.org/0000-0003-0278-1771
}

Contact: Khalid.Said@waldenu.edu

\begin{abstract}
More than 50\% of business failures in the United States are because of leaders' inability to manage working capital. This qualitative, multiple case study is grounded in the cash conversion cycle theory. The purpose is to explore the strategies bank leaders have used to improve working capital management in three banks in Kentucky to increase bank profitability and improve financial stability. Data were collected using semistructured interviews with three different banking leaders who have implemented successful working capital strategies. Using methodological triangulation and Yin's five-step data analysis resulted: (a) risk and liquidity, (b) top-down approach, and (c) investment approach. The findings from this study include strategies for improving the use of working capital, leading to business profitability and increases in employment opportunities.
\end{abstract}

Keywords: working capital management; cash conversation cycle; profitability; banking industry

Date Submitted: September 21, 2020 | Date Published: May 14, 2021

Recommended Citation

Said, K., \& Doll, Y. (2021). Strategies to improve financial profitability in the banking industry. International Journal of Applied Management and Technology, 20, 52-70. https://doi.org/10.5590/IJMAT.2021.20.1.03

\section{Introduction and Background}

Working capital management (WCM) is essential for efficient operation of organizations because it ensures effective use of financial resources (Kieschnick et al., 2013). WCM is an area of interest to many researchers because it prevents liquidity problems and improves the capacity of the organization to manage severe financial problems or any other unexpected change (Gill \& Biger, 2013). WCM allows business leaders to maintain a production schedule as well as sales (Ogbo \& Ukpere, 2014). Additionally, business leaders normally use a working capital line of credit to carry out the day-to-day activities of an organization (Tahir \& Anuar, 2016). Organizations need working capital lines of credit to (a) pay for labor, (b) create a stock to meet the consumers' demand, (c) acquire raw materials, and (d) provide goods on credit for its customers (excluding banks). The banking industry is highly regulated, and banks use ratio metrics when it comes to working capital. For simplicity in this study, WCM is the term used to improve financial profitability. 
According to the U.S. Securities and Exchange Commission (SEC, 2013), more than $50 \%$ of business failures in the United States are because of business leaders' inability to manage working capital. The companies with limited access to financing must effectively use working capital to avoid cash flow discrepancies. Cash flow is important to company sustainability, and enough cash is needed to make payment for daily expenses and purchases. Bank managers need increases in cash flow to increase profitability, which enables banks to provide loans to customers. This study focuses on WCM strategies and banking business profitability. The study findings may help financial business managers change or modify their strategies to become more efficient in managing working capital and improving cash flow.

\section{Problem Statement}

WCM presents a cash flow challenge for business organizations (Karadag, 2015). Inefficient working capital management contributes to more than $50 \%$ of business failures (SEC, 2013). The general business problem is that some bank managers' inefficient use of WCM negatively affects profitability. The specific business problem is that some bank managers lack WCM strategies to improve banking profitability.

\section{Purpose Statement}

The purpose of this qualitative, multiple case study was to explore WCM strategies that bank managers use to improve banking profitability. The specific target population for this study were three managers from three different U.S. banks located in Lexington, Kentucky, who have successfully implemented WCM strategies to increase bank profitability. The findings from this research may help improve banking profitability and contribute to social change by increasing business growth, resulting in more employment opportunities for people in the community. Employment opportunities may increase tax revenue for the government and result in an improved community standard of living.

\section{Conceptual Framework}

The conceptual framework for this study was the cash conversion cycle (CCC) theory. Gitman (1974) first introduced the concept of the CCC and stated that an efficient CCC is necessary for WCM. According to Gitman, the CCC period represents the number of days between when business owners pay for the raw materials and when they receive cash from account receivables. CCC is about how quickly business leaders turn resources into cash flow (Lin et al., 2016). According to CCC theorists, a short CCC will increase business profitability (Lin et al., 2016).

The turnaround of the cash indicates the efficiency of WCM. Oseifuah and Gyekye (2017) stated that a longer accounts payable period, shorter receivable period, and shorter inventory period shorten the CCC. The conceptual framework applies to this study because the theory helps explain how bank managers can remain profitable using WCM, which includes management of accounts receivable, accounts payable, and inventories.

\section{A Review of the Professional and Academic Literature}

\section{Cash Conversion Cycle}

The conceptual framework for the study was the CCC, which is an effective way to evaluate the efficiency of a company's operation. The CCC examines a metric system for businesses that studies the effectiveness at which a company converts inventory into sales or cash. For this study, the CCC theory was used to help explain how bank managers can remain profitable through WCM, which includes management of both accounts receivable 
and accounts payable. A short CCC will increase business profitability, according to CCC theorists (Lin et al., 2016).

CCC indicates the efficiency of WCM. According to Das (2015), the CCC is the time between the business' purchase of raw material and receipt of cash from sales, which indicates the CCC is an active measure of liquidity of the business over time. The components of CCC are sales outstanding days, accounts receivables, accounts payable, collection period, and inventory turnover period. Cristea and Cristea (2016) suggested the firms can enhance profitability by reducing sales outstanding days, inventory turnover days, and accounts payable days outstanding.

CCC affects a company's profitability. A decreased CCC can increase the profitability of enterprises (Lyngstadaas \& Berg, 2016). Similarly, Cristea and Cristea (2016) examined the relationship between CCC and corporate profitability for manufacturing companies. Cristea and Cristea found an increase in the CCC decreases the profitability of the firms. Holding cash for no planned goal decreases the opportunity for making a profit.

\section{Working Capital Management}

WCM negatively affects growth because the companies that have limited access to financing use working capital as a substitute for cash to fulfill operational business needs. Therefore, small- and medium-sized enterprises (SMEs) facing borrowing constraints should diligently consider how the business should use WCM strategies during value creation (Zeidan \& Shapir, 2017). Eya (2016) examined the impact of WCM on firm performance. In a Nestlé Food case study, Eya used behavioral finance theory and the economic order quantity model to understand the capital management of the Nestlé Food company in Nigeria. Eya found a positive relationship among WCM and current ratio, a quick ratio, and a return of asset. Eya showed that WCM is necessary to ensure cash generation for businesses to meet their operational activities and for debt payment.

\section{Assets and Liabilities}

A company's assets and liabilities determine the amount of working capital needed for business continuity and profitability. The difference between total assets and current liabilities affects a firm's profitability, risk, and the value of the organization. Maama et al. (2016) stated short-term and long-term management of the company's current liability and current assets affect a firm's performance. According to Nag and Arickal (2016), WCM depends on current assets. Current assets can be easily converted into cash to meet companies' day-to-day activities to run the business. Lyngstadaas and Berg (2016) stated that to increase performance, business leaders need to keep the working capital to total assets ratio high. Sufficient assets and working capital enhance a company's profitability.

Effective management of working capital is necessary to meet business operational and investment needs. Business leaders calculate working capital by subtracting the current liabilities from the current assets (Talonpoika et al., 2016). Current assets are items in the company's balance sheet that are easy to convert to cash within a year (Delen et al., 2013). The current assets include cash, cash equivalents, short-term deposits, inventory, finished goods, prepaid expenses, account receivables, and marketable securities. Current liabilities are a financial obligation that is payable within a year (Lyngstadaas \& Berg, 2016). The current liabilities are accounts payable, wages payable, income tax payable, accrued liabilities, short-term debts, and other financial obligations. WCM is an approach to fill the gap between current assets and current liabilities (Tran et al., 2017). Management of current assets and current liabilities could improve cash flow.

Managers can take various WCM approaches. The two popular approaches are aggressive and conservative (Tahir \& Anuar, 2016). In an aggressive WCM approach, managers finance fixed assets through long-term debt, which can be risky yet profitable to the business (Tahir \& Anuar, 2016). The conservative WCM 
approach epitomizes the cash level, and in this approach, managers finance permanent assets to meet all or part of seasonal needs (Tahir \& Anuar, 2016). The conservative WCM approach is appropriate if the firm prefers to expand.

The economic value added (EVA) framework measures a company's profitability. Kratz and Kroflin (2016) studied the impact of WCM in the EVA framework. The authors showed an explanation gap when it comes to the predictability of the possible impact of the working capital on EVA. No general rule indicates an increase in working capital will necessarily increase EVA framework, and the decrease in net working capital will not significantly increase in EVA (Kratz \& Kroflin, 2016). Kratz and Kroflin concluded that reducing net WCM will not grow shareholder value in all cases.

Few authors in the literature explored the effect of the CCC on net profit ratio, return on equity, inventory holding period, and cash ratio. Aravind (2016) found a positive correlation between cash conversion and net profit ratio but found a negative relationship with a return on equity in Indian manufacturing companies. Indian manufacturing firms had high payable days outstanding, moderate sales outstanding days, and high inventory days outstanding (Arvind, 2016). Aravind did not find any evidence or relationship between working capital and profitability during various states of the economy. Tsagem et al. (2015) investigated SMEs in Nigeria and found a positive relationship among the inventory holding period, CCC, and cash ratio. Tsagem et al. concluded that efficient WCM is desirable for business survival and growth, especially in developing economies countries.

\section{Working Capital Components}

A thorough understanding of how working capital components affect the business cycle is necessary to minimize risk and improve cash flow. Contrary to accounts receivable, accounts payable is cash going out, and business leaders could maintain liquidity through delayed payment terms to use funds to meet other business needs (Desai et al., 2016). The amount of accounts receivable and accounts payable varies during the money management cycle, and therefore, an effective WCM strategy is necessary to meet business operational activities (Bendavid et al., 2017). Effective WCM includes risk assessment strategy, credit debt collection policy, and credit risk-bearing approach (Nehf, 2017). Effective management of working capital involves understanding the time required to turn the inventory into sales, the business's ability to pay the liabilities, and the time to collect money from a sale (Talonpoika et al., 2016). Scholars define working capital in multiple ways, and various approaches exist in measuring working capitals (Guariglia \& Mateut, 2016). A thorough understanding of working capital and avenues to manage the components of working capital depends on the effectiveness of corporate governance.

WCM components have a significant effect on an organization's profitability. Usman et al. (2017) examined the impact of WCM components on a firm's profitability. The WCM components are receivable days, inventory days, payable days, CCC, and current ratio. During analysis, Usman et al. considered the firm's size, age, and leverage as well as the country's growth and financial crisis, which could affect the components of WCM. The study findings resulted in discovering the contrary impact of inventory days, receivable days, payable days, and the CCC on the firm's profitability. In the study, Usman et al. found extended recovery periods affected the accessibility of the supply of material, which impacted the firm's operations and profitability.

Inventory management. Inventory management is essential to meet the sales demand. Elsayed and Wahba (2016) studied the relationship between inventory level and business performance. According to Elsayed and Wahba, the business inventory level depends on the organizational life cycle stage. The organizational leaders develop their strategies to fit the inventory system and organization settings. Elsayed and Wahba found the design of an inventory system is not a linear process but rather a dynamic process that evolves with the power and interest of stakeholders. They showed a negative relationship among inventory, sales ratio, and organizational performance in the early growth stage and the maturity stage. There was a 
positive and significant relationship between inventory and performance during the rapid growth stage and the recovery stage. Elsayed and Wahba (2016) stated that the organization needed to keep its inventory at a certain level to meet the sales forecast.

Liquidity. Liquidity management is essential for companies in all industries. The lack of liquidity management could lead to a severe financial problem, including insolvency and bankruptcy. Malik et al. (2016) studied the impact of liquidity management in the healthcare industry. Liquidity measures a company's ability to pay short-term debts, usually with less than 1-year maturity date. Malik et al. (2016) found a negative relationship between profitability and liquidity, meaning a reduction in liquidity will lead to an increase in profitability. Gaughan and Koepke (2014) used current ratio, average payment period, day's cash on hand, and debt-to-capitalization period to analyze the liquidity of 600 U.S. hospitals. Gaughan and Koepke found liquidity has a significant impact on hospitals' profitability.

Business leaders need to make a correct assessment of their business liquidity position to make informed business decisions. According to Richards and Laughlin (1980), incorrect evaluation of liquidity could result in business leaders not being able to understand the firm's working capital. Moreover, a wrong evaluation of liquidity may subject creditors and investors to risk. The authors added that the deterioration of a firm's liquidity is a result of lower accounts receivable turnover and extended account collection period. Some leaders use tools such as current ratio, acid-test ratio, and accounts receivable turnover rate to evaluate liquidity (Richards \& Laughlin, 1980). Traditionally, business leaders view current ratio as an accurate indicator of a company's liquidity. The current ratio shows the firm's ability to meet its financial obligations. The acid test ratio relates to businesses' current liability, current assets, cash on hand, and accounts receivables.

Factors such as changes in credits and collection policy affect accounts receivable rates. According to Richards and Laughlin (1980), current ratio, accounts receivable rate, and acid test give a wrong indicator of a business's liquidity position, and they focus primarily on operating cash flow. Therefore, they recommended using the CCC to measure a business' liquidity position instead of the acid test. The business leaders use the CCC to evaluate liquidity by looking into a business' borrowing capacity and the volatility of cash flow (Richards \& Laughlin, 1980). The authors noted business leaders need a better understanding of the interrelationship of CCC, a business's unused borrowing capacity, cash flow volatility, and future cash flows to get a useful insight into a business's liquidity. Ahmad (2016) examined the relationship between profitability and liquidity in the banking sector. In this quantitative study, Ahmad found business leaders can achieve favorable profitability through bank liquidity management.

Cash flow. Positive cash flow is important to increase the liquidity position of the company. The cash management is to maintain a balance between the appropriate level of the cash needed to run the business and marketable securities to reduce the risk of insufficient funds for operation. Abimbola and Jegede (2017) examined the relationship between cash management practices and the performance of SMEs in Nigeria and found a definite relationship between SME performance and cash management practices. Ogbeide and Akanji (2017) examined the relationship between cash flow and financial performance of insurance companies in Nigeria. The authors found cash flow from financing activities increased the financial performance of the insurance companies. According to Ogbeide and Akanji, the size of an insurance company did not affect increasing financial performance. The authors showed cash flow was a significant contributor to the financial performance of the insurance firms in Nigeria. They found the cash flow from operating activities significantly increased the financial performance of insurance firms. Financial managers face many challenges related to how to manage financial ratios because economic crises and government rules can affect the amount of cash the business holds at any time (Eya, 2016). Business leaders need to know how much cash they need to keep running their business. Holding a large amount of cash could lead to a loss in profitability because of a lack of cash investment, whereas holding a small amount of cash could disrupt the activities of a firm (Eya, 2016). 
Cash management. Cash management is essential for positive cash flow. Nwarogu and Lombagah (2017) examined the cash management and performance of listed firms in Nigeria. The objective of this study was to investigate the effect of cash management on the performance of listed service companies in Nigeria, understand the impact of the CCC on profitability, and ascertain the impact of cash holding on the profitability. Moreover, Nwarogu and Lombagah (2017) explored the effect of free cash flow on profitability, an effect of growth on profitability, and analyzed the effect of business size on profitability. The researchers found a significant positive relationship among CCC, cash holding, and return on firms' assets, whereas cash flow and firm size had a negative return on assets.

\section{Governance}

The effectiveness of WCM relies on the overall governing mechanism of a company. The governance oversight includes the handling of current assets, current liabilities, accounts payable, and inventory, which are the components of working capital (Bahar et al., 2017). Maintaining quick turnaround on accounts receivable and delaying or differing in accounts payable means more cash on hand for the business, and adequate inventory level minimizes the risk of not meeting the customer's demand and lowering inventory-related cost (Nuhiu \& Dermaku, 2017). Kayani et al. (2019) examined the firm's effect of corporate governance on WCM. Kayani et al. (2019) found a positive relationship among WCM, corporate governance, and firm performance. They recommended short-term WCM and long-term corporate governance.

One aspect of governing mechanisms is monitoring and controlling working capital. Fiador (2016) supported the notion of improving the governing mechanism to manage the efficiency of the working capital. Fiador measured the governance mechanism in the context of the CCC, inventory, and accounts receivable and payable and found that it affected the efficiency of WCM. The other influencing factors were firm size, age, and profitability (Fiador, 2016). According to Price Waterhouse Coopers (PWC, 2018), networking capital of globally listed companies increased by $9.4 \%$ from 2017 to 2018. An increase in net working capital could improve the capital investment of these firms (Prasad et al., 2019). Therefore, effective corporate governance is necessary to improve the management of working capital for a business's profitability.

\section{Method}

\section{Purpose, Research Question, Population, and Design}

The purpose of this qualitative, multiple case study was to explore WCM strategies that some bank managers have used to increase profitability in their business. A case study design allows a researcher to collect data through a small sample size in a specific setting (Yin, 2017). For this research, the multiple case study design included three different banking companies, and data were collected from purposely selected participants from three different banks. This design introduced different perspectives on the study research question. This main research question guided this study:

What working capital management strategies do bank managers use to improve profitability?

The following interview questions supported the central research question:

1. What working capital management strategies do you use?

2. How do those strategies work to improve profitability?

3. Please provide some examples of how those strategies have worked.

4. What barriers do you encounter in using WCM strategies to increase bank profitability? 
5. Which strategies have not worked and how have you adapted or changed them to be a better fit or to be more effective?

6. How do you assess the effectiveness of WCM strategies?

7. What additional information would you like to share regarding how you use WCM strategies to increase profitability?

The research sample included three U.S. bank managers from three different banks in Lexington, Kentucky, who successfully implemented WCM strategies to increase their banks' profitability. The participating bank managers received a consent form to participate in the research, and, after signing the form, three separate semistructured interviews were conducted. In addition, a variety of additional bank documents were reviewed for information on WCM.

\section{Data Reliability, Validity, and Analysis}

Data reliability and validity are important in any research study as research quality measures (Yin, 2017). Reliability and validity are two elements that all researchers should address while collecting and analyzing data to uphold the quality measures of the study. Reliability is the ability of others to repeat a study and achieve similar results (Alshenqeeti, 2014). Validity, on the other hand, refers to the accuracy of the assessment (Bolarinwa, 2015).

After the interviews were completed, a verbatim transcript was completed, followed by the process of member checking. Member checking was conducted by meeting the selected bank managers for a second time after the transcripts were written to ensure the accurate interpretation of the bank managers' ideas and to ensure their success strategies were accurately documented. Member checking also ensures study credibility (Harper \& Cole, 2012). In addition to using an interview protocol, data were also obtained from the various company documents and were provided by the participants. Collecting data from multiple sources assured obtaining methodological triangulation (Yin, 2017). At the completion of the interviewing process and document retrieval, the interviews were coded using Yin's five-step data analysis process.

Yin's five-step data analysis process included compiling, disassembling, reassembling, interpretation, and conclusion (Yin, 2017). Then the data were imported into NVivo 11 software to verify the analysis and coding. Coding enables similar group patterns to emerge into common research themes (Stuckey, 2015). The NVivo 11 software assisted in organizing the data into patterns and themes to derive the findings and significance of the study.

The five-step data analysis was followed, and data saturation was sought to assist with the reliability and validity of the study findings. Data saturation is collecting enough data to find the answer to the central research question. According to Fusch and Ness (2015), data saturation is a point in the research where any additional information does not add value to the research. Data saturation was ensured through methodological triangulation, selecting an adequate sample size, and selecting qualified participants who met the selection criteria, asking open-ended interview questions followed by probing questions, and using company documents as another point of perspective.

\section{Presentation of the Findings}

The interview responses, analysis, and company documents provided by the participants helped identify various success strategies that were grouped under three major themes: 
1. Theme 1 includes risk and liquidity in working a management strategy. The participants discussed risk management, liquidity and its impact on working capitals, and managing the components of working capital.

2. Theme 2 was a top-down approach. This includes capital budgeting to enhance working capital and the use of risk-adjusted return in capital allocation for the operation of individual company units.

3. Theme 3 includes aggressive, conservative, and hedging working capital approach. The participants discussed cash flow, cash flow forecasting, and working capital management strategies applicability to meet business needs.

The themes and their corresponding frequency from the semistructured interviews and company documents are depicted in Table 1.

Table 1: Frequency of Themes

\begin{tabular}{lcc}
\hline Themes & N & Incidence \\
\hline Risk and Liquidity & 66 & $39 \%$ \\
Top-down approach & 58 & $34 \%$ \\
Investment approach & 46 & $27 \%$
\end{tabular}

\section{Emergent Theme 1: Risk and Liquidity}

All participants separated working capital into two groups: permanent working capital and temporary working capital. The participants noted both groups of working capital are prone to credit risk, liquidity risk, market risk, and operational risk. Managing all risk is essential for the effectiveness of working capital (Njoroge, 2018). Among all risks, the participants identified credit risk as having a significant impact on WCM because bank managers issue lines of credit to generate income. Yeboah and Yeboah (2014) found credit risk affected the bank's profitability. Participant 2 (P2) noted they have clear procedures and policies to identify, deter, and mitigate credit, operational risk, and liquidity risk. P2 provided the researcher with company documents entitled Bank Liquidity Management Tools and Monetary Policy for review. All participants stated that they optimize financial functions to address accounts receivables, inventory management, and accounts payable, which are components of working capital. All participants noted that the approach in WCM stems from their risk management strategy.

$\mathrm{P}_{3}$ reported that both accounts receivable and accounts payable are subject to systematic and unsystematic risk. P3 provided documents for review, which included management of receivables, risk assessment tools, and their bank's auditing framework. P2 supported the risk management notion by describing a strategy to optimize working capital used to reduce the risk associated with accounts receivable, increase accounts payable, and manage inventory. Eya (2016) noted the importance of cash generation to meet business operational activities and for debt payment. $\mathrm{P}_{3}$ stated, "We have sound account receivable function, account payable practices, effective bargaining strategy for favorable credit terms, and volume rebate programs, and benchmarking vendor contacts to the industry standard to improve our cash flow." As such, all participants stated prioritizing accounts receivable and accounts payable management as a risk-deterring strategy.

All participants noted the cost implications to their businesses resulting from risk. P3 said, "We are aware of the risk that hinders us from getting money from debtor soon, negotiating credit terms with bank vendors, and lowering bank interest cost." P1 posited overhead expenses could affect working capital, and, therefore, business leaders must lower overhead costs. According to Leventis et al. (2011), banks are facing liquidity risk, and bank leaders have incentives for managing working capital to avoid the cost and regulatory challenges. $\mathrm{P}_{3}$ noted that bank leaders use explicit knowledge available in the Basel Accord for using working capital through 
risk assessment. All banks comply with the Basel Accord to identify and track risk-related data for the banking industry. The data in the Basel Accord include all types of banking risk. All participants noted that the bank leaders who take and manage their risk clearly understand the scope of the risk. Participants reported that working risk-adjusted capital allocation is within an organizational limit, and the risk-taking activities are in alignment with business strategies and are a corporate goal.

All participants noted the use of technology to shorten the CCC and improve the efficiency of working capital. P2 stated, "We have implemented a vendor portal, giving vendors access to invoice and electronic payment. The use of technology helped us to resolve a dispute, robust reporting, and resolves delinquent accounts, which affect the company cash flow." According to $\mathrm{P}_{3}$, the company leaders optimize financial functions through business intelligence to improve cash management. For example, P3's company's use of sound business intelligence software enhanced the accounts receivable function, accounts payable practices, effective bargaining strategy for favorable credit terms, and volume rebate programs. $\mathrm{P}_{3}$ stated their robust business analytics are used to help track cash flow forecasting by looking at key metrics in their balance sheet and income statements.

P3's company leaders use business intelligence tools to manage working capital turnover in days sales outstanding (DSO) and days payables outstanding (DPO). According to Zeidan and Shapir (2017), both DSO and DPO affect cash flow optimization, which is essential for the management of operating working capital. Cash flow optimization is contingent on CCC (Lin et al., 2016). P3 presented documents relating to DSO and DPO. The review of the documents revealed that the variation in operating working capital resulted from changes in the CCC. An extended cash conversion period, with longer account receivable days, could result in a shortage in cash flow, whereas more accounts payable days may enable managers to hold on to their cash for liquidity purposes.

P3's company leaders compared cash flow forecasting with the key metrics in their profit-and-loss statement and their balance sheet to track the effectiveness of their WCM. According to Weber (2018), analysts forecast earnings per share and long-term growth earnings to better understand the company's cash flow. Business leaders could use forecasting techniques to understand cash flow from CCC, which could be looking at historical data, anticipated sales, and investment results. P3 provided month-by-month inflow and outflow cash charts and added that "this information ensured us that we have access to cash to meet an ongoing business obligation." Moreover, the company documents reviewed during the interview and analysis process included cash credit, bank guarantee, structured cash flow financing, and short-term finance with the use of business intelligence tools. The effective cash flow forecast through effective business intelligence tools could help managers foresee future cash flow needed for WCM.

All participants noted the importance of liquidity position in WCM. According to Richards and Laughlin (1980), incorrect evaluation of liquidity could result in business leaders not being able to correctly allocate working capital. Bank managers must comply with the regulatory body on capital holding requirements. P2 said that, in multiple instances, the banks borrowed from other banks when the security market price declined or the business needed additional funds to meet the reserve. According to P2, borrowing to meet liquidity need is better than selling securities, which can be expensive. P2 added that the leaders found effective borrowing was more beneficial than calling back outstanding loans or placing an embargo on new loans. The CCC concept is suitable to measure of liquidity of the firm over time (Das, 2015). The business leaders use the CCC to evaluate liquidity by looking into a business's borrowing capacity and the volatility of cash flows (Richards \& Laughlin, 1980). All participants stated that banks maintain liquidity levels by ensuring the correct proportion of depositor's funds that could be demanded in any period.

When asked to expand upon the strategy the company used to maintain their liquidity position through WCM, $\mathrm{P}_{3}$ noted that cash holding and investment nature depend on the size of the bank. $\mathrm{P}_{3}$ stated that because their company is a small bank and is expanding, the company has less cash holding. P3 continued, "Since we are a 
small bank, we do not hold a large sum of liquid cash to meet normal transactions." The cash flow depends on CCC (Richards \& Laughlin, 1980). Therefore, a shorter CCC improves cash flow (Lin et al., 2016), which business leaders use to mitigate the risk associated with the components of working capital. P3 provided a document that shows factors affecting the bank's cash flow, which included business profitability, overdraft, working capital, credit or arrears, and taxation. Umoren and Udo (2015) examined the impact of WCM on liquidity and profitability and found a positive relationship among bank performance, cash holdings, and the size of the bank. Therefore, participating company leaders may use aggressive, conservative, or moderating investing strategies to maintain liquidity positions based on the growth, size, and operating cash flow requirement.

The business leaders use the CCC to evaluate liquidity by looking into a business' borrowing capacity and the volatility of cash flows (Richards \& Laughlin, 1980). P2 mentioned that their company set up communications with big depositors regarding their scheduled withdrawals. P2 said that the company held more cash when the bank credit is less available, and the probability of refinancing debt is lower. P1 stated their company leaders look at the holistic business operating environment and foreseeable risk and have a ready source of cash on hand as a strategic contingency plan. Moreover, all participants noted that a business leader should have access to alternative sources of funding to meet short-term cash obligations.

\section{Emergent Theme 2: Top-Down Approach}

All participants stated that WCM involves holding cash required to meet regularity guidelines and budgeting of working capital throughout organizational units. Budgeting requires allocating appropriate funding for business operations (Samuelsson et al., 2016). The Federal Deposit Insurance Corporation Improvement Act (FDICIA) imposed a substantial penalty for banks that do not meet the minimum capital requirement (Walter, 2019). P3 provided the bank's FDICIA compliance guideline brochure for review. P3 noted inefficient capital allocation through budgeting could result in liquidity constraints affecting bank activities in all units. According to $\mathrm{P}_{3}$, the banks need to determine the capital necessary to support each significant bank activity and bank leverage. According to P2, over the past few decades, the bank leaders have been working on developing and instituting company-wide capital allocation strategies or budgeting strategies for their bank activities. Richardson and Taylor (2012) noted budgeting decisions are limited to organizational leaders in the top-down approach. All participants indicated that the bank's leaders adopted the top-down budgeting approach, in which the company calculates the working capital needed down to the level of individual products, business transactions, and maintaining customer relationships.

P2 stated that prior bank leaders allocated working capital based on risks related to the bank's credit portfolio. In 1993, P2's bank formed a risk and capital analysis department to measure and develop risk-adjusted profitability measurements from corporate to departmental units. The bank leaders watch for non-hedgeable risk that originates at the corporate level and affects the business unit underneath. Then, the leader applies risk-adjusted working capital allocation to all business units. The bank leaders need to apply risk-based working capital allocation in budgeting (Froot \& Stein, 1998). P2 suggested optimal working capital allocation to minimize non-hedgeable risk. According to P2, the bank has developed a proven methodology to allocate capital to each business unit, which depends on risk and return. P2 added that "now we quantify the capital necessary to support all banks' activities, whether it is fee-based, trading activities or traditional lending. We know the exact amount of capital required for the functioning of the bank's 23 business units." Therefore, according to the participant, the risk-based working capital allocation in each unit could provide a uniform approach to enhance the bank's performance.

P1 noted that each business unit, from top to bottom in the bank, operated in AA rating standards, and managers calculate standalone risk for each unit. The business units are under consumer and commercial banking. P1 provided the list of business units and briefly discussed the risk to these units and the impact of working capital to mitigate the identified risks. According to P1, managers evaluate each unit in a top-to- 
bottom strategy based on three types of risk: credit risk, market risk, and business risk. "We evaluate how these risks affect the individual units how it contributes towards the over organizational risk" (P1). Then, with the risk management approach, the bank leader analyzes each component of working capital, cash flow, and budgets to fund the units. P2 said, "we calculate the economic impact of each of the above risks on an annual basis and decide the effectiveness of working capital. It will help us with working capital budgeting for the next fiscal year." P1 said, "our top-down risk assessment approach allows how to aggregate working capital at various levels without compromising performance. We calculate credit risk at the individual loan level.”

P1 provided the documents relating to sensitivity analysis, risk-modeling features, graphs, and reports from Monte Carlo simulations. The document review resulted in discovering that the P1 company leaders calculate risk using value-at-risk framework at each departmental unit. P1 mentioned, for a mortgage and high equity loan, the managers calculate risk using a Monte Carlo simulation. According to P1, each quarter, managers brief top management on risk and economic profit of individual units. P1 provided the document relating to how banks calculate risk-adjusted working capital for each unit. P1 said, "the effectiveness of working capital is calculated using the rate of return (RAROC) on the capital in which we divide the rate-adjusted net income by the total amount of capital assigned based on the risk calculations." Ward and Lee (2002) used the RAROC framework to analyze the risk of financial institutions and found RAROC enabled business leaders to make strategic and tactical decisions needed to allocate amounts of working capital required to mitigate risk. Grundke (2010) stated a risk-integrated approach usually involves a top-down approach in banks. However, all participants noted managers should explore the effectiveness of working WCM by thoroughly understanding the business landscape and operating requirements.

All participants said that by allocating working capital in each unit from the top down, managers know the bank's optimal capital structure requirement. All participants brought their company's risk-management documents to the interview. All participants stated market friction affects each unit directly or indirectly. The market frictions are limited public information, collections, and business negotiations. P1 posited the importance of measuring the benefits of financial leverage to costs when doing capital budgeting for each unit. According to P1, high financial leverage could add distress to banks. All participants stated that calculating the risk and volatility of each unit is important to the bank's entire capital structure.

Capital budgeting is one primary concern to all three bank managers. Froot and Stein (1998) stated that, in the capital budgeting process, business leaders allocate capital to mitigate the cost of external financing to improve cash flow. Capital budgeting requires cash flow, which results from CCC (Richards \& Laughlin, 1980), and the overall variability of cash flow is essential to evaluate risk in individual business units within the company. According to P1, the allocation of working capital also depends on the cost of external financing and cost associated with short capital falls. Froot and Stein (1998) noted business leaders allocate capital budgeting to mitigate the cost of external financing. P2 added that leaders evaluate the performance of their business units as residual income, which is the ex-post measure of business unit performance. The interview findings revealed that the participating bank managers pay attention to working capital while doing capital budgeting for the company, including all units.

\section{Emergent Theme 3: Investment Perspectives Approach}

Working capital is the difference between a company's current assets and current liabilities. Maama et al. (2016) stated WCM is short-term and long-term management of the company's current liability and current assets, which affects a business' profitability and sustainability. P1 stated that a bank's failure to manage working capital could result in bankruptcy. P1 noted that, in the last two decades, more than 500 banks in the United States went bankrupt. According to $\mathrm{P}_{3}$, their company is growing, and its current liabilities exceed current assets, and, therefore, the company deploys an aggressive working capital strategy by funding current liabilities with minimal current assets. However, P2 stated that their company has more current assets versus current liability, reflecting that their company is adapting conservative working capital strategies. The 
interviewed participants noted that their companies use all three types of WCM strategies (aggressive, conservative, and hedging).

The participants provided insight into three types of investment strategies to manage working capital. Maswadeh (2015) used aggressive, moderate, and conservative working capital strategies to study company profitability. According to P2, aggressive strategies have high risk, but profitability is high. P1 noted the aggressive strategies are suitable if business leaders want to finance fixed assets as part of WCM. In an aggressive WCM approach, the manager finances fixed assets through long-term debt, which can be risky yet profitable to the business (Tahir \& Anuar, 2016). P1 said the conservative strategy involves low risk and yet maintains profitability. The conservative WCM approach epitomizes the cash level, and, in this approach, managers finance permanent assets to meet all or part of seasonal needs (Tahir \& Anuar, 2016). According to $\mathrm{P} 1$, in a conservative strategy, liquidity risk is low at the cost of a large interest outlay. P2 noted the bank experienced a negative relationship between profitability and aggressive WCM. The findings revealed that managers used the tenet of $\mathrm{CCC}$ to optimize cash flow, and business leaders use aggressive and conservative working capital to improve cash flow based on business needs.

All three participating companies have similar aggressive asset management strategies. P2 noted that, in many instances, return on investment increased because of the high operating cycle of the company's current assets. P1 suggested the business leader should adopt an aggressive strategy on current liabilities and seek a conservative strategy on current assets. According to P1, such action will balance between the risk and return. Moreover, P1 added, if managers use an aggressive strategy in the management of current assets and management of current liabilities, both risk and yield could increase. P2 noted a hedging strategy is financing working capital with moderate risk and profitability in which the business leaders finance assets with debt instruments with the same maturity.

The participants stated that the company leaders investigated multiple triggering factors such as credit, operational, market, and liquidity risk that affect WCM strategies. P2 provided company documents that listed 13 risk-triggering factors. P2 noted that risk factors could be controlled through hedging. According to DeAngelo and Stulz (2015), hedging is a tool banks use to reduce asset-related risk. In moderate or hedging strategy, business leaders adequately adjust company assets with its current liability (Yeboah \& Agyei, 2012). $\mathrm{P}_{3}$ stated that, in a hedging strategy, the company leaders finance assets with debt instruments with the same maturity. According to P2, the hedging strategy is about utilizing long-term sources of financing for long-term assets. Maswadeh (2015) found a stronger relationship between hedging strategies and profitability than aggressive strategy. P2 noted the company leaders financed temporary working capital with short-term sources of finance. P2 brought a chart that illustrated the bank's WCM strategies. The chart included information on how the bank managers conducted risk versus cost trade-offs using aggressive, conservative, and hedging WCM strategies. According to P1, the risk the bank leaders should not tolerate is liquidity risk and non-tradeable risk. The interview and document review revealed that managers tailored WCM based on their risk appetite.

Information asymmetries could affect WCM. P2 said, "we encounter information asymmetries, which could result in the mishandling of our investments." Ineffective aggressive and conservative strategies could affect the bank's liquidity position. According to P2, tying cash flow to fixed investment could result in liquidity constraints. P1 said WCM strategy requires business leaders to manage the balance between liquidity and profitability. P1 added that liquidity is essential for banks to meet short-term obligations, which is ensuring the banks have liquid funds to meet customers' withdrawals. All participants stated that they maintain a high liquidity level to protect against future uncertainties.

P3 presented a document that shows the bank benchmarking liquidity exposure to other banks. The document showed how bank leaders compare core deposits to total assets and loans to deposits while making a commitment to lend money. Analysis of the document resulted in finding the $\mathrm{P} 3$ bank is exposed to less 
liquidity risk than other banks in comparison. Moreover, the $\mathrm{P}_{3}$ bank relies more on the core deposits to fund its assets than its counterparts. $P_{3}$ said, "we measure our efficiency based on our cash holdings." Nwarogu and Iormbagah (2017) found a significant positive relationship between cash holdings and return on firms' assets. $\mathrm{P}_{3}$ added, "this does not mean we do not put funds in the idle investment vehicles if the return is higher than holding cash on hand. We are on a constant lookout for how we can maximize the funds we receive from customers, creditors, and ensure an appropriate mix of funds in possessions." All participants supported debt financing because of cost and tax implications. Participants noted managers reserve cash for customer transactions, as precaution measures and speculation purposes.

P1 said that the business leaders need to monitor current assets and keep them at a realistic level. According to Nag and Arickal (2016), WCM depends on current assets. All participants brought their companies' current balance sheets to the meeting. However, P1 discussed the information in the balance sheet in depth. P1 noted their bank's balance sheet was different than a general company balance sheet. The balance sheet showed an accurate tradeoff between profit and risk. P1 suggested keeping the working capital ratio low and letting the cash circulate for smooth cash flows. All participants agreed proper cash flow forecasting is essential for WCM. Salas-Molina et al. (2017) highlighted the importance of cash flow forecasting for cash management. Business leaders could utilize forecasting techniques to understand cash flow from CCC, which could be accomplished by looking at historical data, anticipated sales, and investment results. P1 viewed accounts receivable and accounts payable in terms of time and money. According to P1, the effective means to manage working capital is purchase at a low price, sell high, collect money early, and pay late. Each participant noted the importance of sequential and proper cash flow forecasting.

\section{Applications to Professional Practice}

The results present banking leaders with information about the risk and liquidity position to improve a bank's profitability. The findings supported risk management to maintain liquidity, which is essential in WCM to meet liabilities. Kumar (2016) and Ahmad (2016) analyzed and evaluated the liquidity position of the company through the components of working capital and found a firm's liquidity has a positive impact on profitability. Moreover, bank managers could use business intelligence tools to manage DSO and DPO to improve CCC.

The investment approach stated in the findings could significantly improve CCC and profitability. Mansoori and Rostami (2017) stated that proper investment in working capital could decrease risk and improve leverage. The results showed that the RAROC approach is effective in improving cash flow. Ward and Lee (2002) noted that RAROC enables business leaders to make strategic and tactical decisions needed to allocate amounts of working capital required to mitigate risk. RAROC depends on the right investment strategy. The findings resulted in discovering that the participating firms' managers used conservative, moderate, and aggressive investment strategies based on the business cycle to maintain adequate cash inflow to address short-term and long-term debt obligations.

The findings supported budgeting to remove the constraints affecting bank activities. The adequate capital budget allocation strategy mentioned in the study findings could enable business leaders to support significant bank activities to meet the shortfall in working capital. The study findings revealed the implementation of budgeting practices through a top-down approach. The bank leaders could use a top-down approach to funnel down strategic decisions to departmental levels, eliminating information asymmetry relating to the management of working capital. Therefore, departmental-level bank managers have a better understanding of how to manage working capital components to improve cash flow leading to improved performance. 


\section{Recommendations for Further Research}

Effective WCM strategies are essential for bank leaders to improve profitability (Samson et al., 2012). The study focused on WCM strategy in small commercial banks and was limited to banks in the Lexington, Kentucky, area. Future research could expand the geographical location and include large banks or other financial institutions. Moreover, researchers could use a quantitative research method to examine the relationship between different factors of WCM and the bank's profitability. This study included holistic strategies of WCM from the executive perspective. Future research could focus on the components of working capital, which are accounts receivables, accounts payables, and inventory management, and identify strategies to improve these components for bank profitability.

One study limitation was focusing on small banks, and, therefore, future research in other (larger) financial institutions could provide a holistic approach in WCM that could benefit both small and large commercial banks. Additionally, involving more researchers in future research could eliminate the risk of bias and improve the accuracy of the data. We did not ask for sensitive data, which could benefit the study. Future researchers could seek sensitive data that may require company permission for the participants to share. Finally, adding more participants to the study could provide an improved perspective in WCM.

\section{Final Thoughts}

The purpose of this qualitative, multiple case study was to explore strategies bank leaders use to achieve profitability. WCM strategies could help bank managers control their finances and make a profit. We found strategies to improve WCM. The participants provided strategies in the context of risk and liquidity, top-down approach, and investment approach.

The study findings revealed that successful bank leaders manage working capital by minimizing risk. A topdown approach includes capital budgeting from the executive leaders to the departmental-level leaders to ensure a bank's liquidity position. Bank liquidity depends on cash flow. An appropriate investment approach could help bank leaders attain enough cash flow. WCM should be a part of a bank's overall financial management strategy for sustainability and business growth. 


\section{References}

Abimbola, O. A., \& Kolawole, O. A. (2017). Effect of working capital management practices on the performance of small and medium enterprises on Oyo state, Nigeria. Asian Journal of Economics, Business, and Accounting, 3(4), 1-8. https://doi.org/10.9734/AJEBA/2017/35237

Ahmad, R. (2016). A Study of relationship between liquidity and profitability of Standard Chartered Bank Pakistan: Analysis of financial statement approach. Global Journal of Management and Business Research, 16(1), 1-7.

Alshenqeeti, H. (2014). Interviewing as a data collection method: A critical review. English Linguistics Research, 3, 39-45. https://doi.org/10.5430/elr.v3n1p39

Aravind, A. (2016). Modeling and constraining inflationary and pre-inflationary eras. [Unpublished dissertation.] The University of Texas at Austin.

Ashvin, R. (2017). Impact of financial management on profitability: Evidences from Indian petrochemical sector. Indian Journal of Commerce and Management Studies, Educational Research Multimedia \& Publications, India. 8(2), 47-52. http://scholarshub.net/index.php/ijcms/article/view/68/62

Bahar, A., Shah, S. (2017, July.) The impact of corporate governance on working capital management efficiency: A quantitative study based on Pakistani manufacturing firms. City University Research Journal 7(2), 272-284.

Bashir, A., \& Hassan, A. (2017). Interrelationship among Basel capital regulation, risk, and efficiency in Pakistani commercial banks. The Business \& Economic Review, 9, 165-186. https://doi.org/10.22547/BER/9.2.7

Basti, E., \& Bayyurt, N. (2019). Factors affecting capital structure choice: New evidence from Turkish nonfinancial listed companies. Journal of Business Economics, and Finance, 8, 53-70. https://doi.org/10.17261/Pressacademia.2019.1015

Bendavid, I., Herer, Y. T., \& Yücesan, E. (2017). Inventory management under working capital constraints. Journal of Simulation, 11, 62-74. https://doi.org/10.1057/s41273-016-0030-0

Bolarinwa, O. A. (2015). Principles and methods of validity and reliability testing of questionnaires used in social and health science researches. Nigerian Postgraduate Medical Journal, 22, 195-201. https://doi.org/10.4103/1117-1936.173959

Cristea, C., \& Cristea, M. (2016). The impact of the working capital management on firm profitability in the Romanian manufacturing industry Annals of the University Of Oradea, 300, 107-110.

Das, S. (2015). Cash management in IT sector-A study. Journal of Commerce and Accounting Research, $4(3-4), 33-46$.

DeAngelo, H., \& Stulz, R. M. (2015). Liquid-claim production, risk management, and bank capital structure: Why high leverage is optimal for banks. Journal of Financial Economics, 116, 219-236. https://doi.org/10.1016/i.jfineco.2014.11.011

Delen, D., Kuzey, C., \& Uyar, A. (2013). Measuring firm performance using financial ratios: A decision tree approach. Expert Systems with Applications, 40, 3970-3983.

https://doi.org/10.1016/j.eswa.2013.01.012

Desai, M. A., Foley, C. F., \& Hines Jr., J. R. (2016). Trade credit and taxes. Review of Economics and Statistics, 98(1), 132-139. https://doi.org/10.1162/REST a 00534

Elsayed, K., \& Wahba, H. (2016). Reexamining the relationship between inventory management and firm performance: An organizational life cycle perspective. Future Business Journal, 2, 65-80. https://doi.org/10.1016/j.fbj.2016.05.001 
Eya, C. I. (2016). Effect of working capital management on the performance of food and beverage industries in Nigeria. Arabian Journal of Business Management Review 6 (5), 1-7. https://bit.ly/2QASoJM

Fiador, V. (2016). Does corporate governance influence the efficiency of working capital management of listed firms: Evidence from Ghana. African Journal of Economic and Management Studies, 7, 482-496. https://doi.org/10.1108/AJEMS-08-2015-0096

Froot, K. A., \& Stein, J. C. (1998). Risk management, capital budgeting, and capital structure policy for financial institutions: An integrated approach. Journal of Financial Economics, 47, 55-82.

Fusch, P. I., \& Ness, L. R. (2015). Are we there yet? Data saturation in qualitative research. The Qualitative Report, 2O(9), 1408-1416. https://doi.org/10.46743/2160-3715/2015.2281

Gaughan, P., \& Koepke, D. (2014). Hospital liquidity and capital investment: Healthcare financial management. Journal of the Healthcare Financial Management Association, 68(10), 94.

Gill, A. S., \& Biger, N. (2013). The impact of corporate governance on working capital management efficiency of American manufacturing firms. Managerial Finance, 39, 116-132. https://doi.org/10.1108/03074351311293981

Gitman, L. J. (1974). Estimating corporate liquidity requirements: A simplified approach. Financial Review, 9, 79-88. https://doi.org/10.1111/j.1540-6288.1974.tbo1453.x

Grundke, P. (2010). Top-down approaches for integrated risk management: How accurate are they? European Journal of Operational Research, 203, 662-672. https://doi.org/10.1016/j.ejor.2009.09.015

Guariglia, A., \& Mateut, S. (2016). External finance and trade credit extension in China: Does political affiliation make a difference? European Journal of Finance, 22, 319-344. https://doi.org/10.1080/1351847X.2012.762030

Harper, M., \& Cole, P. (2012). Member checking: Can benefits be gained similar to group therapy? The Qualitative Report, 17, 510-517. https://doi.org/10.46743/2160-3715/2012.2139

Karadag, H. (2015). Financial management challenges in small and medium-sized enterprises: A strategic management approach. EMAJ: Emerging Markets Journal, 5, 26-40. https://doi.org/10.5195/emaj.2015.67

Kayani, U. N., De Silva, T. A., \& Gan, C. (2019). Working capital management and corporate governance: A new pathway for assessing firm performance. Applied Economics Letters, 26, 938-942. https://doi.org/10.1080/13504851.2018.1524123

Kieschnick, R., Laplante, M., \& Moussawi, R. (2013). Working capital management and shareholders' wealth. Review of Finance, 17, 1827-1852. https://doi.org/10.1093/rof/rfso43

Kratz, N., \& Kroflin, P. (2016). The relevance of net working capital for value-based management and its consideration within an Economic Value Added (EVA) framework. Journal of Economics \& Management, 23, 21-32. https://bit.ly/3noinFa

Kumar, S. (2016). Is the US consumer credit asymmetric? Scottish Journal of Political Economy, 63, 194-215. https://doi.org/10.1111/sjpe.12082

Leventis, S., Dimitropoulos, P. E., \& Anandarajan, A. (2011). Loan loss provisions, earnings management and capital management under IFRS: The case of EU commercial banks. Journal of Financial Services Research, 40, 103-122. https://doi.org/10.1007/s10693-010-0096-1

Lin, W. T., Horng, M. S., \& Chou, J. H. (2016). Relationship of cash conversion cycle and PRGap with firm performance: An empirical study of Taiwanese companies. Investment Management and Financial Innovations, 13, 293-299. https://doi.org/10.21511/imfi.13(3-2).2016.01 
Lyngstadaas, H., \& Berg, T. (2016). Working capital management: Evidence from Norway. International Journal of Managerial Finance, 12, 295-313. https://doi.org/10.1108/IJMF-01-2016-0012

Maama, H., Kusi, S., \& Nsowah, J. (2016). Exploratory study into the components of working capital among selected SMES in the Sunyani Municipality. Sunyani Polytechnic Journal, 1(1), 187-203.

Mansoori, D. E., \& Rostami, R. (2017). Evaluate the relationship between risk management and working capital management in companies accepted in Tehran Stock Exchange during the time period of 2010-2015. International Journal of Environmental \& Science Education, 12, 291-301. http://www.ijese.net/makale/180o.html

Malik, M. S., Awais, M., \& Khursheed, A. (2016). Impact of liquidity on profitability: A comprehensive case of Pakistan's private banking sector. International Journal of Economics and Finance, 8(3), 69. https://doi.org/10.5539/ijef.v8n3p69

Maswadeh, N. S. (2015). Association between working capital management strategies and profitability. International Journal of Accounting and Financial Reporting, 5, 91-98. https://doi.org/10.5296/ijafr.v5i1.6069

Nag, A. K., \& Arickal, B. (2016). A study of working capital management through ratio analysis with reference to Bharat heavy electrical limited. International Research Journal of Management and Commerce, 3 (4), 1-11.

Nehf, J. P. (2017). Consumer credit regulation and international financial markets: Lessons from the mortgage meltdown. In C. Lima Marques and D. Wei (Eds.) Consumer Law and Socioeconomic Development (pp. 147-157). Springer. https://doi.org/10.1007/978-3-319-55624-6 11

Njoroge, J. N. (2018). The effect of corporate governance on working capital management for firms listed at the Nairobi Securities Exchange. International Journal of Business and Processes, 2, 14. http://journals.essrak.org/index.php/Business/article/view/63

Nuhiu, A., \& Dërmaku, A. (2017). A theoretical review on the relationship between working capital management and company's performance. Acta Universitatis Danubius. Economica, 13, 56-69.

Nwarogu, A. I., \& Iormbagah. J. A. (2017). Cash management and performance of listed firms in Nigeria. Journal of Economics Management, 18(1), 1-13. https://doi.org/10.9734/JEMT/2017/33719

Ogbeide, S., \& Akanji, B. (2017). A study on the relationship between cash-flow and financial performance of insurance companies: Evidence from developing economy. Revista de Management Compar at International, 18, 148-156. http://www.rmci.ase.ro/no18vol2/02.pdf

Ogbo, A. I., \& Ukpere, W. I. (2014). The impact of effective inventory control management on organizational performance: A study of 7up Bottling Company Nile Mile Enugu, Nigeria. Mediterranean Journal of Social Sciences, 5, 109. https://doi.org/10.5901/mjss.2014.v5n10p109

Oseifuah, E. K., \& Gyekye, A. (2017). Working capital management and shareholders' wealth creation: Evidence from non-financial firms listed on the Johannesburg Stock Exchange. Investment Management and Financial Innovations, 14, 80-88. https://doi.org/10.21511/imfi.14(1).2017.08

Prasad, P., Sivasankaran, N., Saravanan, P., \& Kannadhasan, M. (2019). Does corporate governance influence the working capital management of firms: Evidence from India. International Journal of Corporate Governance, 1O, 42-80. https://doi.org/10.1504/IJCG.2019.098039

PWC. (2018). Working capital report 2019/20. https://pwc.to/2QaaMrs

Richards, V. D., \& Laughlin, E. J. (1980). A cash conversion cycle approach to liquidity analysis. Financial Management, 9, 32-38. https://www.jstor.org/stable/3665310?origin=JSTOR-pdf\&seq=1 
Richardson, H. A., \& Taylor, S. G. (2012). Understanding input events: A model of employees' responses to requests for their input. Academy of Management Review 37(3), 471-491. https://doi.org/10.5465/amr.2010.0327

Samuelsson, J., Andersén, J., Ljungkvist, T., \& Jansson, C. (2016). Formal accounting planning in SMEs: The influence of family ownership and entrepreneurial orientation. Journal of Small Business and Enterprise Development, 2, 691-702. https://doi.org/10.1108/JSBED-12-2015-0167

Samson, A. A., Mary, J., Yemisi, B. F., \& Erekpitan, I, O. (2012). The impact of working capital management on the profitability of small and medium scale enterprises in Nigeria. Research Journal of Business Management, 6, 61-69. https://doi.org/10.3923/rjbm.2012.61.69

Salas-Molina, F., Martin, F. J., Rodriguez-Aguilar, J. A., Serra, J., \& Arcos, J. L. (2017). Empowering cash managers to achieve cost savings by improving predictive accuracy. International Journal of Forecasting, 33, 403-415. https://arxiv.org/pdf/1605.04219.pdf

Stuckey, H. L. (2015). The second step in data analysis: Coding qualitative research data. Journal of Social Health and Diabetes, 3, 7-10. http://doi.org/10.4103/2321-0656.140875

Talonpoika, A. M., Kärri, T., Pirttilä, M., \& Monto, S. (2016). Defined strategies for financial working capital management. International Journal of Managerial Finance, 12, 277-294. https://doi.org/10.1108/IJMF-11-2014-0178

Tahir, M., \& Anuar, M. B. A. (2016). The determinants of working capital management and firm's performance of textile sector in Pakistan. Quality \& Quantity, 50, 605-618. https://doi.org/10.1007/s11135-015-0166-4

Tran, H., Abbott, M., \& Jin Yap, C. (2017). How does working capital management affect the profitability of Vietnamese small- and medium-sized enterprises? Journal of Small Business and Enterprise Development, 24, 2-11. https://doi.org/10.1108/JSBED-05-2016-0070

Tsagem, M. M., Aripin, N., \& Ishak, R. (2014). Impact of working capital management and corporate governance on the profitability of small and medium-sized entities in Nigeria: A proposed model. International Journal of Science Commerce and Humanities (2), 53-65.

Umoren, A. O., \& Udo, E. J. (2015). Working capital management and the performance of selected deposit money banks in Nigeria. British Journal of Economics, Management \& Trade, 7, 23-513431. https://doi.org/10.9734/BJEMT/2015/15132

United States Securities and Exchange Commission (2013). The investor's advocate: How the SEC protects investor, maintains market integrity, and facilitates capital formation. United State Securities and Exchange commission.

Usman, M., Shaikh, S. A., \& Khan. (2017). Impact of working capital management on firm profitability: Evidence from Scandinavian countries. Journal of Business Strategies, 11, 99-112. https://doi.org/10.5539/ijef.v10n9p136

Walter, J. R. (2019). U.S. bank capital regulation: History and changes since the financial crisis. Economic Quarterly, 105(1), 1-40. https://doi.org/10.21144/eq1050101

Ward, L. S., \& Lee, D. H. (2002). Practical application of the risk-adjusted return on capital framework. CAS Forum Summer 2002, Dynamic Financial Analysis Discussion Papers. https://www.casact.org/pubs/forum/o2sforum/o2sfo79.pdf

Weber, M. (2018). Cash flow duration and the term structure of equity returns. Journal of Financial Economics, 128, 486-503. https://doi.org/10.1016/i.jfineco.2018.03.003 
Yeboah, B., \& Agyei, S. K. (2012). Working capital management and cash holdings of banks in Ghana. European Journal of Business and Management, 4, 120-130. https://citeseerx.ist.psu.edu/viewdoc/download?doi=10.1.1.734.9710\&rep=rep1\&type=pdf

Yeboah, B., \& Yeboah, M. (2014). The effect of working capital management of Ghana banks on profitability: Panel approach. International Journal of Business and Social Science, 5(10), 294-306. https://ijbssnet.com/journals/Vol 5 _No 10 September 2014/37.pdf

Yin, R. (2017). Case study research: Design and methods (6th ed.). Sage.

Zeidan, R., \& Shapir, O. M. (2017). Cash conversion cycle and value-enhancing operations: Theory and evidence for a free lunch. Journal of Corporate Finance, 45(C), 203-219. https://doi.org/10.1016/j.jcorpfin.2017.04.014

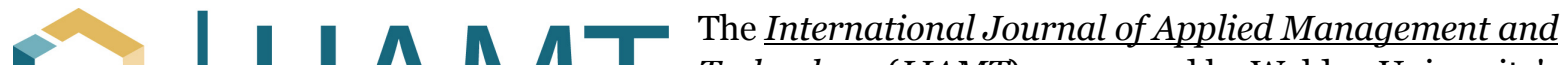
Technology (IJAMT), sponsored by Walden University's College of Management and Technology, is a peer-reviewed, online journal that addresses contemporary national and international issues related to management and technology.
} 